\title{
MENYIAPKAN GENERASI EMAS 2045
}

Oleh: Triyono ${ }^{1}$

\section{Pendahuluan}

Presiden Republik Indonesia ke-3 sekaligus Ketua Dewan Kehormatan ICMI, B.J. Habibie dalam acara pembukaan silaturahmi nasional ICMI yang berlangsung di Kendari tanggal 9-12 Desember 2011 (Sugiharto, 2012) menyatakan bahwa (1) kita kaya tapi miskin, yaitu SDA melimpah tapi miskin penghasilan; (2) kita besar tapi kerdil, amat besar wilayah dan penduduknya namun buruk dalam pengelolaannya; (3) kita kuat tapi lemah, kuat dalam anarkisme tapi lemah dalam tantangan global; dan (4) kita indah tapi buruk, indah dalam potensi dan prospeknya namun buruk dalam pengelolaannya. Mengapa demikian, ---menurut beliau--- karena kita terjangkit "penyakit orientasi" yang lebih (a) mengandalkan SDA daripada SDM, (b) berorientasi jangka pendek daripada jangka panjang, (c) mengutamakan citra daripada karya nyata, (d) melirik makro daripada mikro, (e) mengandalkan cost added daripada value added, (f) berorientasi pada neraca pembayaran dan perdagangan daripada neraca jam kerja, (g) menyukai jalan pintas seperti: korupsi, kolusi, penyelewengan, dsb daripada kejujuran dan kebajikan, dan (h) menganggap jabatan sebagai tujuan daripada sebagai sarana untuk mencapai tujuan/ amanah (power centered rather than accountable).

Ketika bangsa Indonesia menyatakan kemerdekaan 17 Agustus 1945 berpenduduk sekitar 61 juta dan ketika memasuki 100 tahun kemerdekaan, tahun 2045, diprediksi jumlah penduduk mencapai 340 juta dengan 180 juta di antaranya termasuk usia produktif 15-24 tahun. Kondisi tersebut lazim disebut sebagai jendela demografi (window of demography) yang dapat berdampak kepada salah satu dari dua kemungkinan yakni: bonus demografi (demography dividend) atau justru sebagai kutukan demografi (demography diases). Jendela demografi dapat menjadi bonus demografi apabila profil penduduk Indonesia berkualitas, sehingga merupakan potensi bagi negara untuk melakukan akselerasi ekonomi dengan menggenjot industri manufaktur, infrastruktur dan UMKM, karena berlimpahnya angkatan kerja. Sebaliknya, jendela demografi dapat pula berubah menjadi petaka atau kutukan demografi, yang akan menghasilkan pengangguran massal dan menjadi beban negara, manakala negara tidak melakukan investasi sumberdaya manusia (human capital investment).

Pemimpin bangsa Indonesia tahun 2045 adalah mereka yang saat ini sedang duduk di bangku sekolah, baik pendidikan usia dini, pendidikan dasar atau pendidikan menengah. Dalam dokumen Masterplan Percepatan dan Perluasan Pembangunan Ekonomi Indonesia (MP3EI) yang disusun oleh Menko Perekonomian, diharapkan bahwa pada tahun 2025 Indonesia menjadi negara yang mandiri, maju, adil dan makmur dengan pendapatan perkapitan 15.000 dollar AS dan menjadi kekuatan ekonomi 12 besar dunia. Lebih jauh, pada tahun 2045 Indonesia diproyeksikan menjadi satu dari 7 kekuatan ekonomi dunia dengan pendapatan perkapita 47.000 dollar AS.

Sudah barang tentu kita tidak ingin menjadi "pembantu" di negeri sendiri; maka salah satu dari sekian banyak persoalan bangsa ini adalah bagaimana pendidikan harus

\footnotetext{
${ }^{1}$ Rektor Unwidha 2014-2017
} 
"digarap" agar supaya dapat mengantarkan calon-calon pemimpin bangsa tahun 2045 menjadi "generasi emas" yakni generasi yang Energik, Multitalenta, Aktif, dan Spriritual.

\section{Tantangan Indonesia Tahun 2045}

Ketika program Kolonisasi (baca: transmigrasi) pertama kali dilaksanakan di Gedong Tataan, Lampung tahun 1905 jumlah penduduk Indonesia sekitar 29.300.000 jiwa. Sensus Penduduk pertama di Indonesia yang dilaksanakan oleh pemerintah Hindia Belanda tahun 1920, tercatat sebanyak 34.500.000 jiwa (Error! Hyperlink reference not valid. diunduh tanggal 10 September 2016). Jumlah penduduk Indonesia ketika menyatakan kemerdekaan 17 Agustus 1945 sebanyak 60.727.253 jiwa; hanya sedikit yang bisa membaca dan menulis; apalagi yang sarjana sangat sedikit (https://id.wikipedia.org/wiki/ Hindia-Belanda, diunduh tanggal 5 September 2016. Setelah 50 tahun merdeka, tahun 1995 penduduk Indonesia meningkat lebih dari 3 kali lipat yaitu 194.754.808 jiwa (BPS, 2012) dan diproyeksikan menjadi 305.652.253 jiwa tahun 2035 (Bappenas, 2013); dan menjadi 340 juta tahun 2045 (Karyana dan Wahidah, 2011).

Dalam istilah ekonomi kependudukan, Indonesia pada tahun 2045 untuk yang pertama kalinya berada pada kondisi yang disebut dengan jendela demografi (window of demography), karena jumlah penduduk usia produktif 15-64 tahun melebihi dari jumlah penduduk usia non-produktif (usia 0-14 tahun dan 65 tahun ke atas). Tahun 2045 nanti jumlah penduduk usia 0-14 tahun (belum produktif) sebanyak 72.990 .643 jiwa; sedangkan penduduk yang berusia 65 tahun ke atas (tidak produktif) sebanyak 43.705 .044 jiwa; sehingga total jumlah penduduk belum dan tidak produktif 116.695 .687 jiwa. Karena jumlah penduduk usia produktif (15-64 tahun) adalah 224.031 .813 jiwa; maka angka ketergantungan (dependency ratio) sebesar 52,1\% jauh lebih rendah jika dibandingkan dengan angka ketergantungan tahun 1970 yang mencapai 80,2\%. (hasil analisis Sensus Penduduk 1970). Dalam kondisi seperti itu, akan terjadi kenaikan jumlah angkatan kerja potensial, yang menurut Warsito (2015) merupakan keuntungan ekonomis yang disebabkan semakin besarnya tabungan dari penduduk usia produktif sehingga memacu investasi dan pertumbuhan ekonomi. Namun, kondisi tersebut tidak memberikan dampak yang signifikan manakala negara tidak melakukan investasi sumberdaya manusia, bahkan bisa berubah menjadi gelombang pengangguran massal yang akan menambah beban anggaran negara. Adioetomo (2005) menambahkan bahwa efek negatif pascabonus demografi adalah meledaknya jumlah penduduk usia tua, sementara transisi usia muda menjadi usia produktif belum sempurna yang menyebabkan pembengkakan jaminan sosial dan pensiunan sehingga terjadi stagnasi dalam perekonomian nasional karena tabungan dari usia produkif dialihkan sebagai dana talangan untuk membiayai jaminan sosial dan pensiun.

Padahal hingga saat ini Indonesia masih didera berbagai masalah yang belum terselesaikan dengan tuntas; misalnya: korupsi yang makin merajalela, kemiskinan, kualitas pendidikan, dan permasalahan sosial seperti: konflik horizontal antarmasyarakat, peredaran narkoba, terorism, kekerasan sosial, dan berbagai bentuk kriminal lainnya. Jika Indonesia gagal menggarap dan menyiapkan generasi emas 2045, tingkat kriminalitas dan kekacauan akan meningkat karena pelaku dari kriminal tersebut biasanya penduduk usia produktif. 


\section{Empat Skenario Lemhanas}

Pada tahun 1972 terbit sebuah buku dengan judul "The Limits to Growth". Buku ini merupakan hasil penelitian yang disponsori oleh 30 orang dengan berbagai latar belakang keahlian dan profesi dari berbagai negara yang terwadahi dalam forum "The Club of Rome". Penelitian tersebut dilakukan oleh perguruan tinggi terkenal di Amerika Serikat, Massachusetts Institute of Technology (MIT) di bawah pimpinan Dennis I. Meadows. Untuk menjelaskan persoalan yang dihadapi oleh dunia, MIT membuat model ilmiah menggunakan teknik komputer yang canggih. Ada lima variabel yang saling dependen dalam model itu yakni (1) pertumbuhan penduduk, (2) kebutuhan bahan pangan, (3) eksploitasi sumberdaya alam, (4) pertumbuhan industri, dan (5) kerusakan lingkungan. MIT menyatakan bahwa (a) kelima unsur di atas tumbuh dengan kecepatan yang bersifat eksponensial, (b) jika kelima variabel tersebut terus berjalan seperti sekarang; maka planet bumi dipredikais hanya mampu memberi daya dukung kehidupan manusia selama 100 tahun lagi; (c) masih ada kesempatan bagi manusia agar tidak terjadi peristiwa yang digambarkan tersebut, dan makin cepat berbuat, peluang tingkat keberhasilannya makin besar.

Dalam waktu tiga tahun laporan dari Kelompok Roma itu telah diterjemahkan ke dalam 38 bahasa di dunia (di Indonesia: Batas-batas Pertumbuhan). Sejak terbitnya buku "The Limits to Growth", banyak negara menyelenggarakan diskusi atau seminar-seminar; meskipun ada yang pro dan kontra terhadap isi buku tersebut, namun sampai saat ini kita masih merasakan terhadap perubahan kelima faktor tersebut; bahkan makin akut.

Gagasan mengembangkan skenario sebagai upaya menggambarkan masa depan dunia yang dikembangkan oleh Kelompok Roma itu dicoba oleh Lemhanas untuk membangun skenario Indonesia pada tahun 2045. Lembaga Ketahanan Nasional (Lemhamnas) awal tahun 2016 menyusun empat skenario Indonesia pada tahun 2045 dan telah disampaikan kepada Presiden Joko Widodo dan dipaparkan ke pimpinan media massa. Penyusunan dokumen setebal 52 halaman itu melibatkan sejumlah narasumber lintas profesi seperti: birokrat, pengusaha, peneliti, gubernur, antara lain Azyumardi Azra, Dorojatun Kuntjoro Jakti, Emil Salim, Hasyim Djalal, Paulus Wirutomo, Gubernur Sulawesi Barat Anwar Adnan Saleh, Gubernur Bali Made Mangku Pastika, Gubernur Nusa Tenggara Barat Zainul Majdi. Dengan menggunakan pendekatan orientasi transformatif tentang apa-apa yang akan mungkin terjadi di masa depan; ada empat skenario yang dikembangkan oleh Tim Lemhamnas, masing-masing dinamai dengan (1) skenario Mata Air, (2) skenario Sungai, (3) skenario Kepulauan, dan (4) skenario Air Terjun.

Dalam skenario Mata Air, pada tahun 2045, Lemhamnas memproyeksikan Indonesia akan diisi oleh generasi baru yang punya pandangan berbeda dengan pendahulunya. Penduduk Indonesia mulai didominasi oleh generasi yang berpendidikan tinggi, menguasai teknologi komunikasi, aktif bermedia sosial, dan terpapar dengan nilainilai global. Mereka adalah generasi yang berasal dari keluarga biasa tetapi terpisah dari generasi pendahulu. Menurut kelompok ini, mempertahankan kesatuan NKRI harus lebih didasarkan pada prinsip integrasi fungsional dibandingkan dengan integrasi historis. Generasi inilah yang akan menempati posisi penting di bidang politik, birokrasi, bisnis, dan ormas. Mereka akan mengkritik kekuasaan secara lugas dan setiap ketidak-adilan akan dilawan melalui ormas dan kekuatan politik. Kebijakan publik masih diwarnai percampuran kepentingan bisnis dan politik yang menyebabkan suhu politik meningkat. Di tingkat daerah, kualitas institusi dan sumberdaya manusia belum merata, 
menyebabkan masih sering terjadi korupsi, dan gesekan sosial antara putra daerah dengan pendatang sebagai akibat persaingan untuk memperoleh akses sumberdaya ekonomi. Ketimpangan antardaerah masih terjadi sehingga memunculkan aspirasi pemisahan diri.

Dalam skenario Sungai, disebutkan bahwa Indonesia pada tahun 2045 telah mampu keluar dari ancaman "failed state" karena telah menjadi negara industri yang cukup maju dengan struktur ekonomi "belah ketupat" (jumlah kelas menengah lebih banyak dibanding dengan jumlah penduduk miskin maupun konglomerat). Kemitraan antara sektor besar, menengah, dan kecil berjalan baik; didukung oleh infrastruktur, tata ruang, reforma agraria, kebijakan perbankan, fiskal, moneter, dan pasar modal. Hasilnya, sektor agroindustri berkembang dan terjadi peningkatan kemakmuran di pedesaan karena dukungan perkembangan ilmu pengetahuan dan teknologi yang lebih tinggi. Juga terjadi sinergi antara semua pelaku ekonomi dengan pemerintah, parlemen, dunia riset dan pendidikan. Menurut Suhardi Alius (Sekretaris Utama Lemhanas) skenario Sungai ini sejalan dengan prediksi McKinsey (2012) bahwa Indonesia tahun 2023 menjadi negara dengan kekuatan ekonomi ke-7 dunia yang memiliki 135 juta orang kelas menengah dan 113 juta orang pekerja berkemampuan. Namun akan menimbulkan dampak pada kemiskinan, pengangguran, dan ketimpangan sosial serta korupsi yang masih menjadi tantangan besar.

Dalam skenario Kepulauan, disebutkan bahwa pada tahun 2045 Indonesia tetap eksis di tengah-tengah peradaban modern dunia sebagai bangsa yang multietnis, multikultur, bangsa pluralis dengan kadar nasionalis yang tipis. Bangsa Indonesia makin tidak menjiwai kesepakatan dasar bangsa yang tertuang dalam pembukaan UUD 1945. Kekuatan militer makin besar namun belum efektif dan efisien karena penguasaan teknologi kurang memadai. Indonesia disibukkan dengan pengamanan poros maritim dunia dan eksplorasi bawah laut yang dilakukan oleh negara lain di sekitar Indonesia. Regionalisasi pengaturan operasional penerbangan wilayah udara Indonesia masih dikendalikan oleh negara tetangga; termasuk kedaulatan Indonesia masih banyak diatur oleh negara lain.

Dalam skenario Air Terjun, Indonesia di tahun 2045 sudah mulai dengan perencanaan pembangunan yang berbasis rendah karbon. Pembangunan rendah karbon menjadi strategi utama untuk meningkatkan ketahanan energi dalam negeri; sedangkan kedaulatan pangan pada masa sekarang dijadikan fokus utama dalam mengelola ketahanan pangan tahun 2045. Pemerintah secara bertahap meninggalkan praktek pengambilan keputusan berdasarkan pada keuntungan dan kepentingan jangka pendek. Pembangunan dilakukan dengan memperhatikan prinsip keberlanjutan (sustainability); sektor swasta berperan aktif membiayai program-program pembangunan berkelanjutan melalui konsep "green banking and green financing".

"Keempat skenario ini hanya gambaran berbagai kemungkinan yang akan terjadi di masa depan. Ini tergantung bagaimana kemampuan, tekad, dan kecerdasan kita dalam mengelola dan memanfaatkan peluang dan tantangan dalam kerangka NKRI di masa depan", demikian tutur Gubernur Lemhanas, Budi Susilo Soepanji kepada Presiden.

\section{Generasi Emas}

Istilah "generasi emas" menjadi ramai dibicarakan oleh banyak tokoh dan pengamat setelah Mendikbud ---waktu itu--- M. Nuh dalam sambutan peringatan 
Hardiknas 2012 dengan tema "bangkitnya generasi emas Indonesia". Untuk menyiapkan generasi emas tersebut, telah disiapkan kebijakan yang sistematis yang memungkinkan terjadinya mobilitas vertikal secara masif. Untuk itu mulai tahun 2011 telah dilakukan gerakan pendidikan anak usia dini, penuntasan dan peningkatan kualitas pendidikan dasar, penyiapan pendidikan menengah universal. Di samping itu, perluasan akses ke perguruan tinggi juga disiapkan melalui pendirian perguruan tinggi negeri di daerah perbatasan.

Menurut Kopeuw (2015) ada dua pengertian tentang Generasi Emas. Pertama, generasi emas berkaitan dengan bagaimana keadaan generasi Indonesia ketika berusia 100 tahun merdeka, dan yang kedua adalah generasi emas dalam penjabaran kata "EMAS". Sebagai bangsa yang besar dengan modalitas yang sangat luar biasa; baik sumberdaya manusia, sumberdaya alam, sumberdaya kultural, maupun sumberdaya lainnya; sudah saatnya dikelola dan dimanfaatkan dengan sebaik-baiknya untuk sebesarbesarnya kemakmuran dan kesejahteraan rakyat.

Pendidikan mempunyai peran yang sangat penting dan strategis dalam pembangunan bangsa, sehingga pemerintah bertekad memberikan perhatian yang besar terhadap pembangunan pendidikan. Hanya melalui pendidikan, bangsa Indonesia menjadi maju dan dapat mengejar ketertinggalan dari bangsa lain; baik dalam bidang sains, teknologi, maupun ekonomi. Pendidikan juga dimaknai sebagai suatu proses di mana suatu bangsa mempersiapkan generasi mudanya untuk menjalankan kehidupan di masa depan melalui pembentukan dan pendewasaan pengembangan kepribadian agar menjadi insan Indonesia yang berkarakter yakni insan yang beriman dan bertakwa kepada Tuhan Yang Maha Esa, sabar, mampu mengendalikan diri, disiplin, kerja keras, ulet, bertanggung jawab, jujur, membela kebenaran dan kepatutan, sopan dan santun, taat terhadap peraturan, demokratis, sikap kebersamaan, musyawarah, gotong royong, toleran, tertib, damai, anti kekerasan, hemat, dan konsisten, cerdas secara intelektual, emosional, dan spiritual.

Investasi sumberdaya manusia berbeda dengan investasi sektor fisik karena pada sektor fisik, rentang waktu antara investasi dengan tingkat balikan dapat terukur dalam jangka pendek. Investasi pendidikan lebih berjangka panjang, tingkat balikan tidak bisa dinikmati dalam ukuran waktu 1-2 tahun; melainkan belasan atau puluhan tahun. Karena sifatnya berjangka panjang, maka investasi pendidikan memiliki tentang waktu yang panjang pula. Pendidikan bermutu akan dapat diwujudkan apabila upaya pendidikan dapat membantu individu sebagai generasi emas yang sedang tumbuh dan berkembang secara dinamis dan aktif dalam pembentukan diri menjadi insan Indonesia yang berkarakter, cerdas dan kompetitif, serta produktif.

Bagian kedua adalah pengertian generasi emas dalam arti penjabaran kata "EMAS" yaitu Energik, Multitalenta, Aktif, dan Spiritual. Dengan demikian membangun generasi Emas Indonesia 2045 adalah sebuah produk generasi baru yang Energik, Multritalenta, Aktif, dan Spiritual; yakni generasi yang cerdas, siap bersaing di era modern, globalisasi dan penuh kompetitif.

Energik artinya penuh energi atau bersemangat. Dengan bersemangat akan melahirkan rasa optimis dan memiliki kekuatan yang mengarahkan aktivitas hidupnya. Generasi emas adalah generasi yang selalu menunjukkan sehat dan bugar, siap lahir dan batin untuk melakukan aktivitas dan tugasnya dengan baik. 
Multitalenta bisa digambarkan sebagai multiinteligence, baik cerdas dalam hal logika matematika, cerdas dari aspek bahasa verbal, cerdas dalam hal visual spasial, cerdas secara kinestetik, cerdas secara interpersonal, cerdas secara intrapersonal, dan cerdas secara natural. Generasi emas yang kita bangun adalah generasi yang secara terus menerus mau mengembangkan diri dengan menguasai ilmu pengetahuan dan teknologi serta memiliki berbagai talenta.

Aktif berarti giat dalam bekerja dan berusaha yaitu memiliki kemampuan individu untuk mengambil tindakan tanpa harus diperintah; mengerjakan sesuatu melebihi dari yang dipersyaratkan pekerjaan, dan menciptakan kesempatan-kesempatan baru.

Spiritual lebih berkaitan dengan pengalaman keagamaan yang dianutnya. Generasi spiritual menunjukkan kepada generasi muda yang memiliki kualitas kehidupan rohani yang baik, taat menjalankan ajaran agama, taat beribadah, taat berdoa, menjauhkan diri dari hal-hal yang dilarang agama, tidak melibatkan diri pada minuman yang memabukkan, seks bebas, narkoba, maupun gerakan radikalisme.

Untuk bisa menyiapkan generasi emas Indonesia 2045, kunci strategisnya adalah "pendidikan", terumata pendidikan karakter yang berbasis IESQ.

\section{Pendidikan Karakter Berbasis IESQ}

Di samping program wajib belajar 12 tahun, untuk menyiapkan generasi emas 2045, pendidikan di Indonesia perlu lebih memfokuskan pada pendidikan etika dan pendidikan karakter yang berbasis kecerdasan intelektual, kecerdasan emosional, dan kecerdasan spiritual.

Manullang (2013) mengatakan bahwa "the end of education is character", jadi seluruh aktivitas pendidikan semestinya bermuara kepada pembentukan karekter. Kegiatan intra dan ektra kurikuler sebagai inti pendidikan di sekolah harus dilakukan dalam konteks pengembangan karakter. Karakter generasi emas 2045 diharapkan menunjukkan sosok kepribadain yang utuh dan orisinil, apa yang dipikirkan harus sesuai dengan apa yang diucapkan dan apa yang diperbuat.

Kemendikbud sejak tahun 2010 telah memiliki grand desain pendidikan karakter, dan telah beberapa kali direvisi yang berisi: dasar pertimbangan secara konseptual, nilainilai substansi karakter yang dikembangkan, proses pembudayaan, pengembangan, dan pemberdayaan, perangkat pendukung, integrasi ke dalam kegiatan intrakurikuler, kokurikuler, dan ekstrakurikuler, tahapan pembentukan karakter peserta didik, pembiasaan perilaku yang bermuatan nilai dan etika, sampai kepada pengembangan model asesmen dan penilaian.

Karakter adalah nilai-nilai yang melandasi perilaku manusia berdasarkan norma agama, kebudayaan, hukum dan konstitusi, adat istiadat, dan estetika. Beberapa istilah yang mempunyai arti serupa dengan karakter antara lain akhlak, moral, watak, budi pekerti. Pendidikan karakter dipahami sebagai suatu sistem penanaman nilai-nilai perilaku (karakter) kepada warga sekolah yang meliputi: pengetahuan, kesadaran atau kemauan, dan tindakan untuk melaksanakan nilai-nilai; baik terhadap Tuhan Yang Maha Esa, diri sendiri, sesama, lingkungan, maupun kebangsaan sehingga menjadi insan kamil. Atas dasar konsep tersebut, sejumlah karakter yang diharapkan dimiliki oleh peserta didik meliputi: religius, jujur, toleransi, disiplin, kerja keras, kreatif, mandiri, demokratis, rasa ingin tahu, semangat kebangsaan, cinta tanah air, menghargai prestasi, bersahabat, cinta damai, gemar membaca, peduli lingkungan, peduli sosial, dan bertanggung jawab. 
Karakter generasi emas 2045 dapat dibangun secara utuh dan orisinil apabila berbasis IESQ, yakni kecerdasan intelektual (IQ), kecerdasan emosional (EQ), dan kecerdasan spiritual (SQ). Kecerdasan Intelektual (IQ) merujuk kepada kecepatan dan ketepatan aktivitas kognitif dalam memahami, menyelesaikan berbagai masalah, tantangan, dan tugas-tugas. Cerdas secara intelektual berarti cepat dan tepat melakukan aktivitas mental, berpikir nalar, dan pemecahan masalah. Dimensi intelektual mencakup numerik, kemampuan verbal, kecepatan perseptual, penalaran induktif, penalaran deduktif, visualisasi ruang, dan memori. Sedangkan kecerdasan emosional (EQ) merujuk pada potensi kemampuan personal dan interpersonal. Kemampuan personal meliputi kecepatan dalam memahami emosi diri sendiri, mengelola suasana hati, dan memotivasi diri sendiri. Kemampuan interpersonal meliputi kemampuan dalam memahami perasaan orang lain (empati), kemampuan menyesuaian diri, disukai banyak orang, kemampuan memecahkan masalah antarpribadi, keramahan, kesetiakawanan, dan sikap hormat. Kecerdasan spiritual (SQ) merujuk pada sifat-sifat mulia dan nilai-nilai kemanusiaan, kecerdasan yang berhubungan dengan masalah makna dan nilai. Kecerdasan spiritual memposisikan perilaku dan hidup dalam konteks makna yang lebih luas. SQ merupakan pondasi yang diperlukan untuk memfungsikan IQ dan EQ secara efektif. Landasan utama dari suatu pemahaman konsep adalah $I Q$, sedangkan landasan untuk menerapkan konsep dalam bentuk perbuatan adalah IEQ; dan IESQ merupakan landasan pokok dari pembentukan karakter. Pengembangan IESQ secara komprehensif merupakan prasyarat untuk membangun pola pikir esensial, sikap positif, dan komitmen normatif serta kompetensi abilitas.

\section{Wajib Belajar 12 Tahun}

Dasar hukum yang mengatur penyelenggaraan sistem pendidikan di Indonesia pertama kali setelah kemerdekaan adalah Undang-Undang Nomor 4 Tahun 1950 jo. Undang-Undang Nomor 12 Tahun 1954 tentang Pernyataan Berlakunya UU No. 4 Tahun 1950 Dari Republik Indonesia Dahulu Tentang Dasar Pendidikan dan Pengajaran di Sekolah Untuk Seluruh Indonesia; dilanjutkan dengan UU Nomor 2 Tahun 1989 dan UU Nomor 20 Tahun 2003 tentang Sistem Pendidikan Nasional.

Upaya perluasan dan pemerataan kesempatan belajar sebagai cerminan dari azas keadilan sosial di Indonesia dimulai sejak tahun 1974 (Repelita I) dengan membangun gedung-gedung baru Sekolah Dasar; agar dapat menjamin perluasan daya tampung SD bagi $85 \%$ penduduk usia 7-12 tahun pada akhir Pelita I yang diperkirakan sejumlah 23,0 juta. Demikian pula daya tampung pada jenjang pendidikan SMP/MI dan SMA/SMK juga ditambah untuk menampung lulusan SD/MI maupun SMP/MTs agar mau melanjutkan pendidikan ke jenjang yang lebih tinggi.

Kebijakan tersebut juga dibarengi dengan pengangkatan guru SD secara besarbesaran, penyediaan berbagai jenis beasiswa, Gerakan Orang Tua Asuh (GNOTA), dan penyediaan pengadaan buku paket. Saat ini juga telah disediakan Bantuan Operasional Sekolah (BOS), Bantuan Siswa Miskin (BSM), Kartu Indonesia Pintar (KIP), Beasiswa Bidikmisi, Beasiswa Unggulan, dan sebagainya. Bahkan secara politik dan konstitusional, para wakil rakyat telah menyetujui alokasi anggaran bidang pendidikan diatur dalam Undang-Undang Nomor 20 Tahun 2003 tentang Sistem Pendidikan Nasional pada Pasal 49 ayat (1) yang menyatakan bahwa "Dana pendidikan selain gaji pendidik dan biaya 
pendidikan kedinasan dialokasikan minimal 20\% dari Anggaran Pendapatan dan Belanja Negara dan minimal 20\% dari Anggaran Pendapatan dna Belanja Daerah"

Kepedulian pemerintah dalam mewujudkan pendidikan yang berkualitas diawali dengan adanya program pendidikan bermutu. Salah satu dari program tersebut adalah adanya Program Wajib Belajar Pendidikan Dasar 9 Tahun yang dicanangkan pada tahun 1994 sebagai kelanjutan dari Program Wajib Belajar 6 Tahun yang dimulai sejak Repelita III tahun 1984. Akan tetapi sampai tahun 2015 ini Program Wajib Belajar Pendidikan Dasar 9 Tahun belum mencapai 100\%. Data tahun 2015 menunjukkan APK SD/MI/Paket C adalah 110,50 dengan APM 96,70 dan APS 99,09; APK tingkat SMP/MTs/Paket B adalah 91,17 dengan APM 77,82 dan APS 94,97; dan APK tingkat SM/Paket C adalah 78,02 dengan APM 59,71 dan APS 70,61.

Untuk menyongsong generasi emas Indonesia tahun 2045, sudah semestinya pemerintah segera mencanangkan Program Wajib Belajar 12 Tahun dengan harapan dapat meningkatkan daya tampung SMA/MA/SMK dan merata di seluruh wilayah NKRI sedemikian sehingga APS untuk penduduk usia 16-18 tahun mencapai angka di atas $90 \%$

\section{Penutup}

Generasi Emas Indonesia 2045 masih 29 tahun lagi. Saat itu, sebagian dari kita khususnya yang saat ini berusia separuh baya mungkin sudah tiada. Namun sesungguhnya Generasi Emas Indonesia 2045 sudah di depan mata kita sekarang. Anak-anak yang berusia balita hingga yang remaja berada di sekitar kita. Ada yang sedang asyik bermain, ada yang sedang belajar; ada pula yang sedang ngamen di perempatan jalan raya; ada yang menenggak minuman keras, narkoba, atau terlibat dalam tindak kriminal lainnya. Merekalah yang akan memimpin bangsa ini tahun 2045 kelak.

Kita semua patut bersyukur bahwa pada periode 2010-2035 banga Indonesia dikaruniai oleh Tuhan yang Maha Esa potensi sumberdaya manusia berupa populasi usia produktif yang jumlahnya luar biasa. Jika kesempatan emas yang baru pertama kalinya terjadi sejak Indonesia merdeka tersebut dapat kita kelola dan dimanfaatkan dengan baik, insya Allah akan menjadi bonus demografi (demographic dividend) yang sangat berharga. Di sinilah peran strategis pembangunan dan pengembangan bidang pendidikan untuk mewujudkan hal tersebut menjadi sangat penting. Akan tetapi, sebaliknya, bukan mustahil kesempatan emas tersebut berubah menjadi bencana demografi (demography disaster) manakala kita tidak dapat menggarap dan mengelola dengan baik.

Periode 2010-2035 Indonesia harsu melakukan investasi besar-besaran dalam bidang pengembangan sumberdaya manusia sebagai upaya menyiapkan generasi emas Indonesia 2045, yakni suatu generasi ketika bangsa Indonsia berusia 100 tahun kemerdekaan.

\section{Referensi}

Adioetomo, Sri Moertiningsih. (2005). Bonus Demografi: Hubungan Antara Pertumbuhan Penduduk Dengan Pertumbuhan Ekonomi. Jakarta: BKKBN.

Badan Perencanaan Pembangunan Nasional. (2013). Proyeksi Penduduk Indonesia 20102035. Jakarta: Bappenas. 
Badan Pusat Statistik. (2012). Penduduk Indonesia Menurut Provinsi Tahun 1971, 1980, 1990, 1995, 2000, dan 2010. Jakarta: BPS.

Fathul Himam. (2016). "Pembangunan Berwawasan Kependudukan Menuju Generasi Emas Papua", Seminar Nasional Kagama Berkarya Mewujudkan Masyarakat Papua Bangkit, Mandiri, dan Sejahtera. Jayapura, 18-19 Januari 2016.

Hendra Gunawan. (2013). “Indonesia 2045”, dalam Kompas. 5 Maret 2013.

https://id.wikipedia.org/wiki/Hindia-Belanda diunduh tanggal 5 September 2016.

Karyana, Yayat dan Lisnur Wachidah. (2011). "Pengembangan Metode Komponen dalam Proyeksi Penduduk Indonesia 2015-2050 Menggunakan Metode Campuran Dengan Pendekatan Demografi Multiregional", dalam Prosiding Seminar Nasional Penelitian dan PKM: Sosial Ekonomi dan Humaniora. Bandung: Unisba. Vol. 2, No. 1, 2011. pp. 467-476.

Kopeuw, Pilipus M. (2015). Mimpi Memiliki Generasi Emas Sentani. Jakarta: tp.

Manullang, Belferik. (2013). "Grand Desain Pendidikan Karakter Generasi Emas 2045", Jurnal Pendidikan Karakter. Tahun III, No. 1, Pebruari 2013. pp. 1-14.

Meadows, Donella H, et. al. (1980). Batas-batas Pertumbuhan (The Limits to Growth). Jakarta: PT. Gramedia.

Mumammad Nuh. (2012). "Sambutan Menteri Pendidikan dan Kebudayaan pada Peringatan Hari Pendidikan Nasional Tahun 2012". Jakarta: Rabu 2 Mei 2012.

Paslah, Asroni. (2015). "Pencapaian Program Wajib Belajar 9 Tahun”, dalam http:// kompasiana.com/asrony-faslah/pencapaian-program-wajib-belajar-9-tahun, diunduh 10 September 2016.

Prasetyo, Z. K. (2014). “Generasi Emas 2045 Sebagai Pondasi Mewujudkan Siklus Peradaban Bangsa Melalui Implementasi Kurikulum 2013 di Sekolah Dasar", Makalah Seminar Nasional Kurikulum 2013. Pontianak, 16 April 2014.

Sugiharto. (2012). "Menyongsong Indonesia Emas 2045" Kuliah Perdana Universitas Sarjanawiyata Tamansiswa (UTS) Yogyakarta. Yogyakarta, 17 September 2012.

Warsito, Raharjo Jati. (2015). “Bonus Demografi Sebagai Mesin Pertumbuhan Ekonomi: Jendela Peluang atau Jendela Bencana di Indonesia", dalam Populasi. Vol. 26, No. 1. 2015. pp. 1-19

Wiriosudarmo, Rachman. "The Limits to Growth", dalam http://ki-rawis.blogspot.co.id/ 2010/03/limit-to-growth.html diunduh tanggal 12 September 2016 